\title{
Amphibia, Anura, Microhylidae, Chiasmocleis avilapiresae Peloso and Sturaro, 2008: First record for the state of Acre, southwestern Amazonia, Brazil
}

\author{
Paulo Roberto Melo Sampaio ${ }^{1 *}$, Talisson Ruy Batista da Silva ${ }^{1}$ and Pedro Luiz Vieira Peloso ${ }^{2}$ \\ 1 Universidade Federal do Acre, Laboratório de Herpetologia - HerPet, Campus Universitário Áulio Gélio Alves de Souza. BR 364 km 04 Distrito \\ Industrial. CEP 69915-900. Rio Branco, AC, Brazil \\ 2 American Museum of Natural History, Richard Gilder Graduate School and Division of Vertebrate Zoology (Herpetology). Central Park West at \\ 79th Street, 10024. New York, NY, USA. \\ * Corresponding author. E-mail: herpeton@gmail.com
}

\begin{abstract}
We record for the first time the presence of Chiasmocleis avilapiresae in the state of Acre, Brazil. This microhylid frog is found throughout Amazon in Brazil and no information about its distribution in the Acre state was reported previously. An increase on sampling efforts, revision of material housed in herpetological collections, and use of diverse herpetofauna sampling methods might reveal additional localities and more information about this species.
\end{abstract}

The genus Chiasmocleis includes 25 species distributed from Panama through most of tropical South America, north and east of the Andes (Frost 2010). Several of the species in the genus have been recently described: C. gnoma Canedo, Dixo and Pombal, 2004; C. magnova Moravec and Köhler, 2007; C. mantiqueira Cruz, Feio and Cassini 2007; C. sapiranga Cruz, Caramaschi and Napoli, 2007; C. avilapiresae Peloso and Sturaro, 2008; C. devriesi Funk and Cannatella, 2009; and C. supercilialbus Morales and McDiarmid, 2009. For many of the known species data on geographic distribution and behavior is scarce. Chiasmocleis avilapiresae (Figure 1) has a wide distribution on the Amazon basin, south of the Amazon river, but records are limited to localities in the states of Amazonas, Mato Grosso, Pará and Rondônia (Peloso and Sturaro 2008; Peloso 2009).

On 04 June 2010, one of us (PRMS) found a specimen of $C$. avilapiresae during a herpetofaunal survey in a forest fragment in eastern state of Acre (09 53'45.1" S, $67^{\circ} 18^{\prime} 14.8^{\prime \prime} \mathrm{W}$, elevation $148 \mathrm{~m}$ ), in the municipality of Senador Guiomard. The collected specimen (Figure 1A and $\mathrm{B}$ ) is housed in the herpetological collection of the Universidade Federal do Acre (UFAC-4651). The specimen was on leaf-litter near to small stream during the night.

The herpetofauna of Acre is very diverse with over 100 species (Souza 2009). However little information is available for microhylids, including Chiasmocleis, known from four species: C. avilapiresae (Figure 2; this study), $C$. bassleri, C. shudikarensis Dunn, 1949 and C. ventrimaculata (Andersson, 1945) (Souza, 2009). Unfortunately, to this point, no method have been employed to focus on the sampling of leaf-litter frogs (e.g. pit fall traps with drift fences [Cechin and Martins 2000]) in Acre. The use of additional sampling methods and review of the material housed at the Coleção Herpetológica da Universidade Federal do Acre might reveal novel data on herpetofauna.

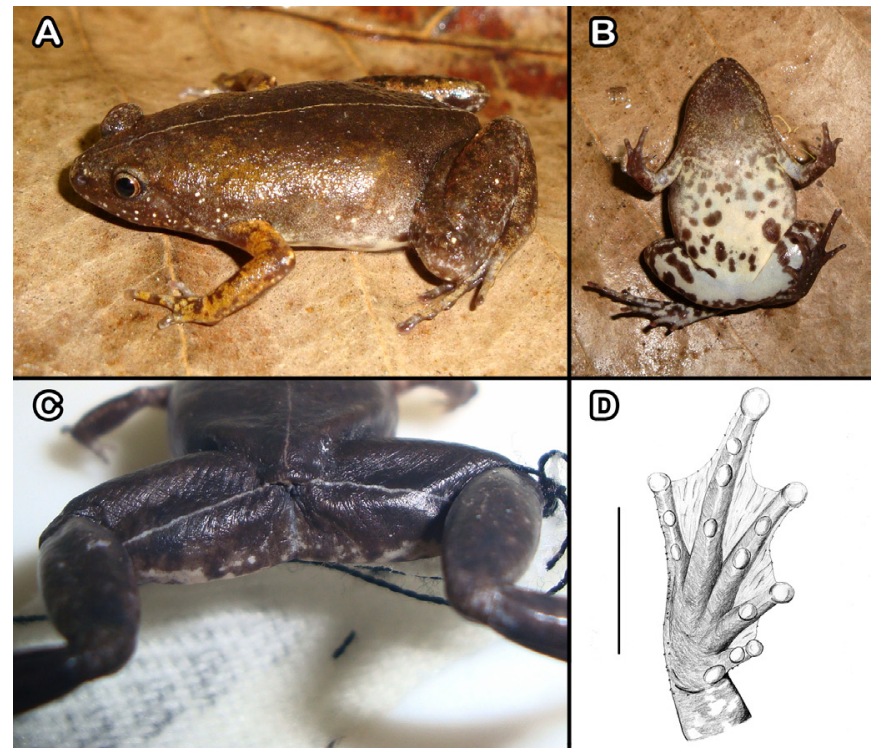

FigurE 1. Chiasmocleis avilapiresae. (A) Dorsal, (B) ventral, and (C) posterior views of a specimen from the state of Acre (UFAC 4651). (D) Drawing of the plantar view of the foot of a male specimen from Aripuanã, Mato Grosso, Brazil (MNRJ 44240), bar $=5 \mathrm{~mm}$. Photos A, B and C by P.R. Melo-Sampaio; D by P. L. V. Peloso.

Chiasmocleis avilapiresae is commonly misidentified as C. bassleri Dunn, 1949, C. shudikarensis and C. ventrimaculata (Peloso and Sturaro 2008). However, C. avilapiresae can be promptly distinguished from $C$. bassleri and $C$. ventrimaculata by the presence of extensive toe webbing in males (Figure 1D) (webbing, absent or basal in males $C$. bassleri and C. ventrimaculata). From $C$. shudikarensis $C$. avilapiresae is distinguished by its bigger size, more robust body and by the absence of an inguinal spot (inguinal spot present in C. shudikarensis). For detailed comparisons among C. avilapiresae and other Chiasmocleis species refer to Peloso and Sturaro (2008). 


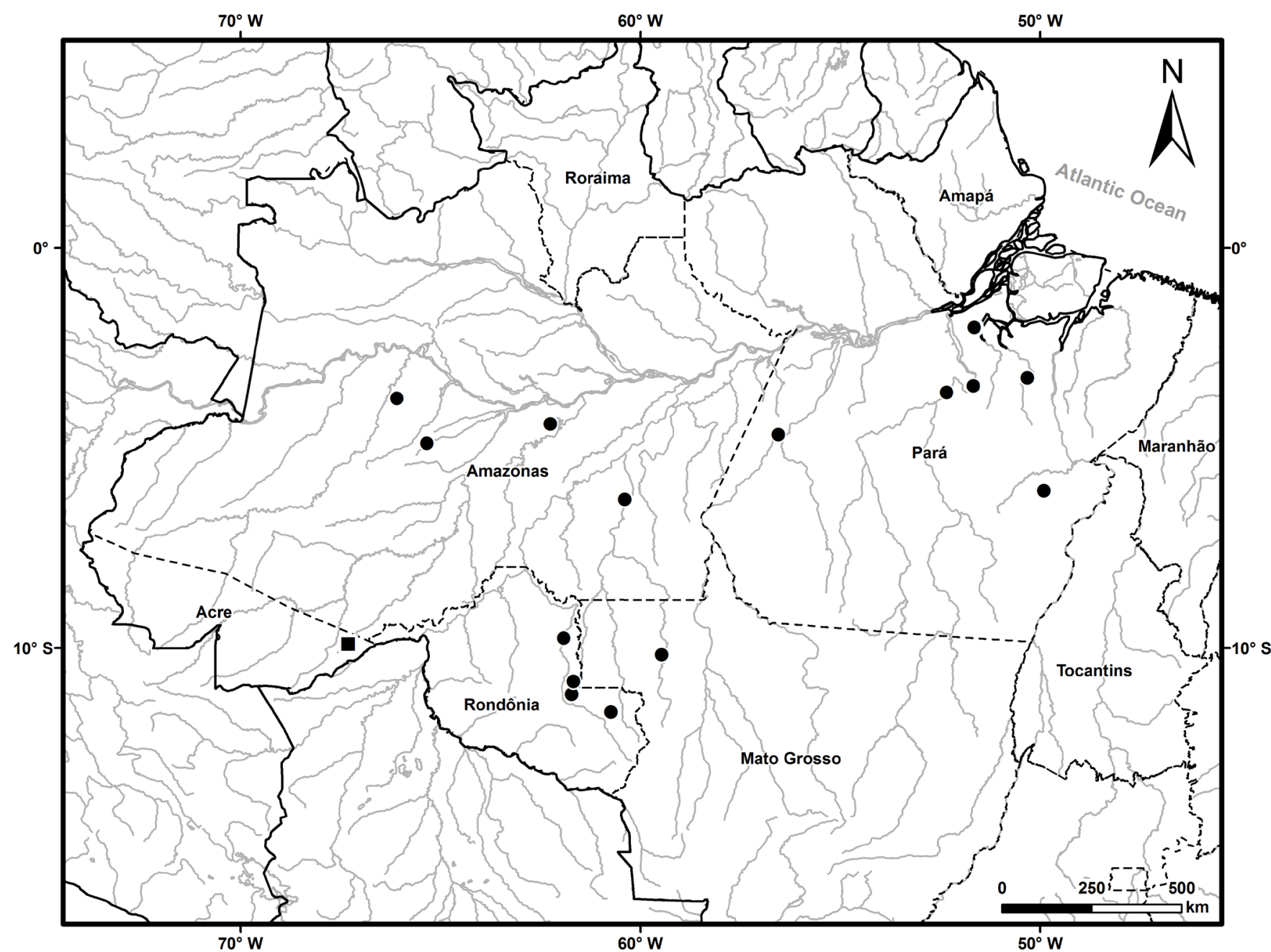

Figure 2. Distribution map of Chiasmocleis avilapiresae throughout Amazonia. Black circles are records presented in Peloso and Sturaro (2008). The square is the new record in the state of Acre, Brazil (this study).

ACKNOWLEDGMENTS: We thank Marcelo J. Sturaro for the help with the map. José P. Pombal-Jr loaned specimens from MNRJ and two anonymous reviewers that critically suggests comments on manuscript. PLVP is supported by a fellowship from Coordenação de Aperfeiçoamento de Pessoal de Nível Superior / Fulbrigth Comission / American Museum of Natural History (Process number BEX 2806/09-6).

\section{LITERATURE CiTED}

Cechin, S.Z., and M. Martins. 2000. Eficiência de armadilhas de interceptação e queda (pitfall traps) em amostragens de anfíbios e répteis no Brasil. Revista Brasileira de Zoologia 17(3): 729-740.

Frost, D.R. 2010. Amphibian Species of the World: an Online Reference. Version 5.4 (8 April, 2010). Electronic Database accessible at http:// research.amnh.org/vz/herpetology/amphibia/. American Museum of Natural History, New York, USA. Captured on 10 June 2010.
Peloso, P.L.V. and M.J. Sturaro. 2008. A new species of narrow-mouthed frog of the genus Chiasmocleis Méhelÿ 1904 (Anura, Microhylidae) from the Amazonian rainforest of Brazil. Zootaxa 1947: 39-52.

Peloso, P.L.V. 2009. Chiasmocleis avilapiresae In IUCN 2010. IUCN Red List of Threatened Species. Version 2010.2. Electronic Database accessible at http://www.iucnredlist.org. Captured on 30 July 2010.

Souza, M.B. 2009. Anfíbios: Reserva Extrativista do Alto Juruá e Parque Nacional da Serra do Divisor, Acre. Campinas: IFCH. 77 p.

RECEIVED: July 2010

REVISED: September 2010

ACCEPTED: November 2010

Published online: December 2010

EDITORIAL RESPONSIBILITY: Marcelo N. de C. Kokubum 